\title{
Chaplaincy as Ministry of Presence: A Case Study for Learners at Ikhwezi Lomso Comprehensive School
}

\author{
Bulelani Bomela \\ Cape Conference of SDA, South Africa
}

\begin{abstract}
Most public schools in South Africa do not have in their organogram, chaplains to serve the mental, physical, spiritual and emotional needs of learners in public schools. Ikhwezi Lomso Comprehensive School is no exception as it falls under government administered (public) schools. Through an interaction with learners, I have discovered that learners at Ikhwezi Lomso Comprehensive School battle with issues which challenge their mental, physical, spiritual, and emotional capabilities. As a result of this, incidences, such as sexual activities, bullying, self-esteem issues and misuse of narcotic drugs and alcoholic beverages, which affect and disrupt their learning continue to be witnessed resulting in unwanted pregnancies, abortions, Sexually Transmitted infections, abuse of drugs and drinking, and unacceptable general behaviour due to lack of discipline. The study seeks to introduce a ministry of presence in the form of chaplaincy, which will work hand in hand with educators in dealing with behavioural challenges and thereby benefiting parents whose time is occupied by work and other challenges.
\end{abstract}

A hybrid approach paradigm is used where a structured questionnaire and interviews, which will be, conducted among the sampled grade 9 class of sixty learners to collect data determining behavioural habits. The hybrid research paradigm used is both quantitative and qualitative.

The study has shown that there is a need for chaplaincy ministry, which seeks to provide a ministry of presence within the school. Chaplaincy deals with day-to-day challenges to learners who are growing in an environment where temptations and youthful challenges are rampant. The intention is to help learners to develop mental, physical, emotional and spiritual abilities. The abilities highlighted will guide the learners' decision-making patterns on matters of sexuality and behaviour and further help those who have already been victims of the highlighted challenges. This will be achieved by conducting seminars on sexuality related matters, behavioural and moral development programmes, debates among learners on these issues and offer mentoring and counseling to challenged learners

\section{INTRODUCTION}

$\mathrm{T}$ the understanding of human behaviour (which is manifested in thoughts and actions) demands actions, which come in a form of a certain ministry and mission to build and develop good thought and actions.

Giddens and Sutton (2010:13) argue, "Sociologists inquire into the human nature and causes of the regularized and repeatable patterns of human thought and conduct." Grulan and Mayars (1988:34) highlight that the enquiries focus on the thoughts and actions, which a person shares as a member of the society.

Sociology is not mission and ministry but rather mechanisms for determining a better way of doing ministry (Clark, 2002:34). Schools are currently home grounds for all kinds of behaviour. These behaviours in most cases temper and disturb the progress of learning which results to high attrition rate. This is clearly articulated by Giddens and Sutton above.

The focus of this paper is mission oriented, offering a redemptive ministry to learners exposed to daily challenges like sex and sexuality, which has adverse results in their schooling if not addressed. Comprehensive Sexuality Education focuses on two pillars, i.e. (1) a learner must remain healthy in his/her schooling period (free from TB, HIV and AIDS, STIs and unwanted pregnancies) and (2) that the learner needs to finish the schooling system with no delays and on time. This programme is envisaged to acknowledge and bring divine initiatives together with human efforts in helping a young mind living in the city in decision-making about sex and sexuality and other related dangers to learners. This ministry of presence programme will not only enhance good, ethical, sound, and responsible decision making about sex but result to minds that are focused on education as priority, value sexual purity and combat sexual promiscuity, pregnancies, and abortions among learners.

\section{SAMPLING METHODS}

The sampling technique that will be used in this study is nonprobability sampling, using a purposive/ judgmental/expert sampling. According to McMillan and Schumacher (2001:174-175) advocate that nonprobability sampling happens when "the researcher uses subjects who happen to be accessible or who may represent certain types of characteristics." This also means the type of sampling used was purposeful as the researcher selected particular elements (grade 9) of the population, which will provide representation and/ or even be informative about the subject interest researched. The representative of the elements of the population will be determined from Grade 9 Class considering all the learners (boys and girls) and educators, the sampling will be deliberately selected. Purposive Sampling is done to achieve the following: (i) maximum variation to ensure the spread and reasonable representation, (2) data richness to ensure that there is enough and sufficient date for synthesis 
and (3) study scope or match of the scope ensuring that the study matches the objectives. Results have been analysed using a qualitative/quantitative data analysis in the form of a text and asking questions.

The target for questionnaires was to receive at least $80 \%$ of the responses and the interviews were between chosen boys and girls within the class to avoid congestion and to many activities during interviews. A representative approach is a motivation for interviews by which both boys and girls will be participating.

Below is a table showing the demographic ratio of learners participating in responding to the questionnaire.

Table 1. Demographic Ratio of learners for Questionnaire

\begin{tabular}{|c|c|c|c|c|}
\hline Gender & Number/\% & Race & Place of Stay & Grade \\
\hline Female & $38-63.3$ & $\begin{array}{c}\text { African } \\
\text { Black }\end{array}$ & Township & 9 \\
\hline Male & $22-36.7$ & $\begin{array}{c}\text { African } \\
\text { Black }\end{array}$ & Township & 9 \\
\hline
\end{tabular}

As indicated above, for interviews a representative sample approach was used for the target group. It was inclusive of boys and girls and where they stay. Below is the demographic ratio of learner representation for interviews.

Table 2. Demographic Ratio of learners for Interviews

\begin{tabular}{|c|c|c|c|c|}
\hline Gender & $\begin{array}{c}\text { Number \& } \\
\text { Age }\end{array}$ & Race & Place of stay & Grade \\
\hline Female & 5- (15,16) & $\begin{array}{c}\text { African } \\
\text { Black }\end{array}$ & Township & 9 \\
\hline Male & 5- (15-16) & $\begin{array}{c}\text { African } \\
\text { Black }\end{array}$ & Township & 9 \\
\hline
\end{tabular}

Reliability and Validity of Methods used

MacMillan and Schumacher (2001:407) explain that validity refers "to the degree to which the explanations of the phenomena match the realities of the world." The qualitative and quantitative methods in this research are used to obtain knowledge and information. This selection of research methods chosen was to enhance validity and reliability of the study conducted at Ikhwezi Lomso Comprehensive School.

\section{BIBLICAL FOUNDATION OF THE MINISTRY OF PRESENCE}

\section{The Old Testament Motif}

The record of the Old Testament shows that God Himself, from creation until and beyond with an intimate knowledge of creation, demonstrated his passionate and compassionate involvement in the affairs and welfare of human beings, he had created. At creation mankind enjoyed communion with God and holy Angels (see Gen 3:8). It is a notable fact that the presence of created features, though important for environmental provisions, crowns the ideal community because of God's presence within His creation. This chapter presents a scenario of God whose constant presence was felt by the created beings, "and they heard the sound of the Lord God walking in the garden in the cool of the day..." Though the verse may sound like, at this moment, His visit was a source of alarm but according to Nichol (1978:231), it is pivotal to note that the periodical visits of God towards the close of day when quiet evening zephyrs refreshed the garden had always been occasions of delight for the happy pair. The visibility of God among mankind built a strong foundation for loyalty and dependence upon God. The fall of Adam and even into sin created a lacuna between God and them. This lacuna of sin hides the face of God from mankind (see Isa 59: 2) destroying obedience as the condition for eternal happiness. White (2011:52) argues that Satan moved by envy, he determined to incite them to disobedience and bring upon them the guilty and penalty of sin. Sin separates humanity from God. It tempers with a relationship that would constantly make mankind enjoy the presence of God. Fowler (2000:268) argues echoing the same on the impact of sin and says sin not only shuts away from God but destroys in the human soul both the desire and the capacity for knowing Him. God's interest is to be with His creation even when overwhelmed by sinfulness. Obedience to God is man's response and paying allegiance to His saving relationship. It keeps God's presence always present. Satan's working day and night is to tempt men to distrust God and live a life of being absorbed into self and self-gratification. That which Adam and Even were used to, the presence on God became something unwelcomed and they hide their face from Him. White argues (2011:52) advocates that the divine presence was manifested in the garden. In their innocence and holiness, they had joyfully welcomed the approach of their Creator; but now they fled in terror and sought to hide in the deepest recesses of the garden. This reaction drove them away from God. But God draws nearer to them by enquiring about their position and their current state (see Gen 3:9). God's ministry of presence transcended their state of affairs at the time and offered a ministry of love. His love is a seeker for the lost that He may address the situation. The presence of God is not a silent invisible presence but it is characterized by action founded in His love to better the lives of the offenders (see Gen 3:21).

This ministry of presence founded upon love for the lost soul permeates through ages and can be exhibited in God instructing Moses and Israel to build Him a sanctuary that His presence would be with them (see Ex 25:8). This was a worship centre marked by God's presence and aimed at bringing humanity to pay full allegiance to God and not to Satan. Like Adam and Eve, White (2010:343) argues that by their apostasy the Israelites forfeited the blessing of the divine presence. Yet God sought to bring His presence by commanding Moses to build a tabernacle that would be manifested in their journey. In line with the services performed in the sanctuary, God's presence was about the restoration and transformation of characters for a better life. It is about a change of a lifestyle, leaving sinful ways and desires for a divine standard of living. 
God appointed kings and prophets in Israel as a chosen nation that would epitomize the presence of God and further draw the attention of the nation to true worship and paying full allegiance to God. Israel as a nation provoked God and was constantly lured to idolatry. This apostasy opened to Israel a tide of evil. The duty of the Kings and prophets was mainly to maintain and restore allegiance to God. White (1917:127) argues that God had sent messengers to Israel with the appeals to return to their allegiance. They were the voice of God to bear messages with faithfulness. "They are not to speak their own words but words which One greater than the potentates of the earth has bidden them speak. She continues to highlight that the message is to be "Thus says the Lord, (White, 1917:57). It is an unfortunate situation that most of Israel's kings abdicated their duty by leading the nation to idolatry and thereby moving them away from the presence of God. Some kings became the conduit for Israel's apostasy. Such drifting away weakened the will power and Satan assails the soul and corrupted the mind.

\section{CHRIST'S MINISTRY OF PRESENCE}

\section{The New Testament Motif}

The New Testament also demonstrates an incarnational ministry of Jesus Christ. His earthly ministry shows a man who was an indigenous human, a chaplain par excellence. The Gospels have only a few references to Jesus being in the temple and one of Him in the synagogue at Nazareth. Apart from these, the ministry of Jesus is conducted largely outside the confines of the gathered community of faith. Jesus Christ demonstrated a ministry filled with passion and compassion. He was sympathetic to the needs of people. He presented God's love in a manner appealing to many of His followers. While there are so many instances where Jesus demonstrated a ministry of presence, I will only focus on two, which relate to a ministry offered to change and impact someone's life.

\section{The Story of Mary}

In an event and a setting where the Pharisees would have acted otherwise, Jesus allowed a prostitute to buy Him an exorbitant gift, which was possibly purchased by supposedly dirty money (see Luk. 7:36-50). While His disciples construed this to be a waste of money, $\mathrm{He}$ understood the gesture as a cry for help rather than gifts given for merely to comply with human convention with little meaning. Disciples saw waste in her gesture and Jesus saw a gift in the response of her forgiven sin. In this instance, disciples are still hovering in this woman's past and White argues and says "Simon the host has been influenced by the criticism of Judas upon Mary's gift, and he was surprised at the conduct of Jesus. His Pharisaic pride was offended. He knew that many of his guests were looking upon Christ with distrust and displeasure. Simon said in his heart 'this man if He were a prophet, would have known who and what manner of woman this is that touched Him: for she is a sinner, (White, 2005:566). Jesus' objective to win the woman was achieved.
He accepted the gesture and thus the faith of a victim of circumstances was displayed. Her faith in Jesus is the reason for a later declaration that tax collectors/publicans and harlots will get into the kingdom of heaven before religious persons whose behaviour is anything but Christ like (see Matt 21:31).

\section{Woman Caught In Adultery}

The second incident relates to the woman caught in the act of adultery. While John 8 is presented to prove that Jesus Christ is not only the promised Messiah but God who can forgive sins, it is important to note how this same Jesus dealt with people's behaviours. The chapter presents a woman who has been caught in the act of adultery. Though the focus and the interest of the Scribes and Pharisees were on Jesus' response to the situation as a way of putting Him to test. The argument is to reveal acts of love even towards those whose sexual behaviour is unbecoming. Because there is no indication of the woman brought to Jesus being married where the very word adultery would fit the scenario, it then suffices to say the term adultery could also refer to sexual irregularities like fornication. Jesus' response in verse 11 "Neither do I condemn you; go and sin no more" is two-fold. It revealed the transforming power of God to forgive sins. It also displays love as the foundation of Jesus' ministry and Miroslav argues "human behaviour matters to God who created us and who bound Himself to us with love, (Dederen, 2000:675). This response also indicated that God is opposed to self-destructive behaviour. Jesus in this instance displays words of mercy. He uttered in John 3:17 'For God did not send His Son into the world to condemn the world but that the world through Him might be saved.' What a relief to her, "Jesus words came to the trembling woman as words of mercy in abrupt contrast with the angry words of her accusers (Nichol, 1978:986).

The woman's captors demanded from Jesus the application of law towards such who are caught in immoral activities. He displayed a connection between law and grace. White (1973:10) argues on the connection of law and grace that God's grace and the law of His kingdom are in perfect harmony; they walk hand in hand. While sin must be condemned, Christ's encounter with the woman left a foundation for Christian ethics. Christian ethics must clarify and provide guidance in clarifying what is right and what is wrong. Most importantly Christ ministered to her in a manner that left her sorry for sin and turning away from it.

\section{The Samaritan Woman}

Jesus compassionate and incarnational ministry cuts across ethnic cultures. The woman was not just from Samaria she was a Samaritan, a nation that was despised by Jews. His Jewish background did not blind his overarching greater objective. The narration of the story in John chapter 4 displays the intention of the author to deliberately exhibit Jesus' compassionate ministry towards the vulnerable in this historical event. A close observation concludes that the woman had an issue of sexual conduct. There are also some 
surrounding issues to the woman one may notice the issue of unlawful marriage status (cohabitation) in verse 16-18, sexual immorality, which dented her character and exclusion from the community because of the negative perception. Even Jesus disciples did not see a potential in the woman, as they returned to the well they wondered why Jesus was so concerned about her. Describing her situation William Barclay (1975:148) writes "may it be that she was so much of a moral outcast that the women even drove her away from the village well and she had to come here to draw water? Gangel (2000:74) concurs "about noon the woman came to the well, obviously a social outcast since that hot hour would have been an unlikely time to lug a heavy water jar back into the city. Upon a request of water from Jesus, the woman seems to put a mask to her situation by diverting to a theological debate. This act is an attempt to put a mask and to put an act of confidence and yet she lived a life of misery. Even her community disregarded her status and Ganjel (2000:74) argues

Here was a woman who lived outside the boundaries of any religious or cultural standards of her day. A string of five husbands followed by a lover is certainly not unknown in the twenty-first century, but it is hardly common even in our permissive society with its twisted tolerance for evil. In first century Samaria, such a domestic arrangement was unthinkable.

Her theological strong side could not spare her from Jesus revealing her weaker side, which she aimed at protecting. A question 'where is your husband and a subsequent response 'I have no husband' "was the woman's attempt to keep the secrets of her life concealed, (Nichol 1978:939). This is not an exposure to shame but to offer ministry and service because there was a need, to be saved from sexual morality as she continued to live with a man though she was not married to. This is a ministry offered not just through words, but Jesus presence at the moment filled the gap, emptiness, and loneliness, as she was a cast out. The influence of Jesus ministry and present help together with His transforming power made the woman to be a co-worker with him as she called others to witness a man who revealed past life. A ministry to the vulnerable is a ministry, which is not judgmental, which cuts across cultures, and seeks to transform and to empower. It is a ministry that cannot be remotely offered by incarnational ministry of presence.

\section{CHAPLAINCY: MEANS TO OFFER A MINISTRY OF PRESENCE}

The importance of the ministry of presence has been discussed in the previous sections. Part of the ministry of presence is the function of a resident chaplain. The work of a chaplain is embedded in the very definition, which looks at the general view of what chaplaincy is. Swinton and Mowat (2016:154) have suggested that "the Chaplain, normally an ordained member of the clergy, is thus seen at least traditionally to be the representative of the particular faith community who is sent to work within a specific setting. The introduction and establishment of chaplaincy ministry within the schools is pivotal to deal with life matters as they relate to young people. Young people generally are not so keen to go to church; Church attendance is viewed by some to have restrictions, which hinder their lives. In the United Kingdom and Scotland as governments slowly introduce chaplaincy in health sectors "it has also been suggested that religion and spirituality may be beneficial on several levels and concerning a wide variety of conditions, including lower blood pressure, reduced serum cholesterol levels, reduced levels of pain in cancer sufferers and protection against depression and anxiety, (Swinton and Mowat, 2016:151). Without comparing cultures and settings it is evident that chaplaincy offers and continues to be an important service in the life of a human as Swinton and Mowat continue to argue, " The evidence that does exist helps locate some potential benefits that spirituality and religion could offer at a clinical as well as pastoral level, Swinton and Mowat, 2016:152). The role of chaplaincy, therefore, brings in the effect of building the spiritual and religious foundation, which stabilises life in general. This is by no means an attempt to establish within a school setting or even elevating a certain traditional religion but simply advancing the principles of religion because the role is agenda-free. This means that the role does not proclaim the gospel to seek subscribers to a particular religious belief. It must be understood that the role of a chaplain is different from that of a parish minister though their source of existence is the same.

\section{Key Focus of Chaplaincy Ministry}

Before I can focus on the role of a chaplain, there is a need to look at what a chaplain/chaplaincy is. The Oxford dictionary (2000:sv) describes it as "the office or position of a member of the clergy attached to private chapel, institution, ship regiment, etc. The person working as chaplain is a pastoral practitioner who seeks to build a relationship of trust through compassionate presence and thereby offer help and support to a wide range of people. This person's role is supportive and serves as a counselor and guide to any needs. Unlike a pastor who focuses on a church, a chaplain focuses on a community. The individual offers ministry and Crick (2011:xiii) recognises that "ministry is not just measured by what we do but why and how much we are willing to suffer with and for another human being in the midst of crisis.

In this study, the key focus is on school learners to equip them with a mechanism to cope with issues of life through vigorous coaching classes, one on one counseling session to deal with past baggage and focusing on prospects. While this programme is designed to assist a learner, its implications extend to easing weight and unnecessary stress on parents at home due to unbecoming behaviours as well as contributing to learner's success and capacity in the classroom.

\section{FINDINGS}

1. Learners are children: Children often live within a world of do's and don'ts. This world seeks to build a 
hedge around the lives of children. Once they get used to this world, there is a possibility of losing them to another undesirable world. In most cases the school offers the world of do's and don'ts whether knowingly or unknowingly. Do's and don'ts have a potential to limit the relationship between a parent and a child, or in this case between a learner and an educator. Like any other children, learners at Ikhwezi Lomso Comprehensive School have found a way to adhere to do's and don'ts not because there is a relationship, but presumably because a school is a place where educators exist and not parents. This kind of mentality unfortunately affects life at school as more hours are spent at school than home.

2. Morals: Since the advent of schooling, adults have expected schools to contribute positively to the moral education of children. Unfortunately, it is not always the case. While there is a moral code of conduct at this school it is notable that it instils fear for punishment, and therefore adherence is based on fear that building a character, as a result there are traces of moral decay among learners, which given a benefit of the doubt could also be traced back from a home background. There are issues of drugs, alcohol, teenage pregnancy, bullying, fighting which is perpetuated by anger, and disrespect among learners. There is a high possibility that parents are abdicating their responsibilities when it comes to these issues.

3. Sexual Relationships: One of the vital components of sexuality education in schools and homes is that it teaches children about relationships. Findings of this study indicate that others either influence learners or are peer pressured to be in sexual relationships. The availability and promotion of condoms during Life Orientation classes is misinterpreted as giving license to engage in sex. Debates and talks have revealed that learners only fear HIV and Aids, pregnancy; otherwise, the use of condoms would have been neglected. There are also beliefs especially among boys that one would be insane if not engaging in sex till a certain age. Therefore, abstinence is a trajectory towards being insane and keeping one's virginity is old time.

4. Christian sexual counselling and education: The secret of success and conquering sin in young people like Joseph in the bible lies in the fear of God. Loyalty to God and building faith in the unseen is a rare commodity among learners. There is a lack of noble character building, which result to selfdiscipline by surrendering to the power of the almighty and learning His ways. Learners in the school find it implausible to receive prayer and counselling on matters of life. Educators don't always offer a spiritual father and mother figure and thereby providing spiritual counselling and education to learners.

\section{RECOMMENDATIONS}

Due to the nature of findings, the recommendation of chaplaincy as ministry of presence will address the issues above.

Chaplain Ministry is a specialized ministry offered by an ordained minister/clergy. Among many programmes that the government can provide for public schools is to assign chaplains to offer a specialised ministry to learners and educators. Education is complete when all aspects like academic, social, health and the integration of spiritual guidance and care are provided. White (1903:13) argues that true education means more than the pursual of a certain course of study. It means more than a preparation for the life that now is. It is to do with the whole being and the whole period of existence possible to man. It is the harmonious development of the physical, the mental, and the spiritual powers. It prepares the student for the joy of service in the world and for the higher joy of wider service in the world to come. The Spiritual aspect of education is pivotal to the total development of a learner. "Spiritual needs can be understood as the invisible or inner aspect of humanity needs, including but not limited to meaning, hope, motivation, aspirations, purpose of life and meaningful experience, (MacKinlay, and Trevitt, 2007). It is possible to see negative emotions; attitudes and meaningless life if spiritual needs are not met. The impact of spiritually focused care positively affects learners not only in the life at school but a life in adulthood. Spiritual care giving to learners provides confidence and forms a firm foundation, which helps in time of crisis. Emotional and mental stress to learners due to schoolwork or outside forces like family challenges and relational challenges sometimes cannot not be quenched by mechanical help but could find solutions through spiritual care giving. Hsiao, Chiang and Chien (2010) focusing on spiritual support and guidance within the nursing institutions argue that "spiritual care becomes more important when a person is faced with life issues or life-threatening circumstances that negatively challenge a person's inner tranquility and peace, thus evoking spiritual discomfort or crisis in severe cases. Learners need to be guided through a belief system and to be taught to build the inner strength by trusting in God in every situation.

\section{CONCLUSION}

Ikhwezi Lomso Comprehensive School is one of the schools that could change the game plan and achieve more than just academics but also produce refined learners in terms of behaviour. The ministry of presence has been demonstrated as a continual intervention from the garden of Eden to recreation. This kind of intervention will be the establishment of the ministry of presence programme, which comes in the form of chaplaincy and will be implemented to all learners at Ikhwezi Lomso Comprehensive School. The effectiveness of this programme will be evaluated periodically to ensure its sustainability. This programme will constitute the following: (1) counselling, (2) consultation, feedback and discussions 
with boys and girls and among themselves, (3) training session/s which involve parents and educators, and (4) sexuality education and awareness which looks at disadvantages, challenges and health risks of early sexual debut, myths about sex and traditional views juxtaposed with modern views on sexual behaviour. This programme will include mentorship that will equip the comprehensive school learners with cognitive ability in making sound, ethical and responsible decisions on issues of sex and sexuality.

\section{REFERENCES}

[1] W. Barclay, The Gospel of John. Philadelphia: Westminster, 1975.

[2] R.A. Clark, "Sociology and Faith: Inviting Students into the Conversation." In Teaching as an Act of Faith: Theory and Practice in Church-related Higher Education. Bronx, NY: Fordham University Press, 2002.

[3] R. Crick, Outside the gates: The need for, theology, history, and practice of chaplaincy ministries. Oviedo, FL: Higher Life, 2011.

[4] D.L. DuBois and Karcher, M.J. Youth Mentoring: Theory, research, and practise. In D.L. DuBois \&M.J. Karcher (Eds), Handbook of youth mentoring (pp 2-11). Thousand Oaks, CA: Sage. Doi: 104135/9781412996907.nl. Accessed 19 November 2021.

[5] K.O. Ganjel, John, Homan New Testament Commentary Series. Nashville: Broadman \& Holman, 2000

[6] J.M. Fowler, "Consequences of Sin" on Handbook of Seventh day Adventist Theology. Hagerstown, MD: Review \& Herald, 2000.

[7] Anthony Giddens, and Philip W. Sutton, Sociology: Introductory Readings. $3^{r d}$ ed. Malden, MA: Polity Press, 2010).

[8] Stephen A. Grulan and Marvin K. Mayers, Cultural Anthropology: A Christian Perspective. $2^{\text {nd }}$ ed. Grand Rapids, MI: Zondervan, 1988).

[9] Hsiao, YC.,Chaing, H.Y. and Chein, L.Y,. 2010, 'An exploration of the status of spiritual health among nursing students in Taiwan', Nurse education Today 30(5), 386-392. PMID: 20434243, http://dx.doi.org/10.1016/j.nedt.2009.05.001.

[10] M. MacKinlay, and Trevitt, C., 2007, 'Spiritual Care and ageing in a secular society', Medical Journal of Australia 186 (10 suppl.), S74-S76. PMID: 17516891.

[11] J. McMillan and S. Schumacher, Research in education: A conceptual introduction, $5^{\text {th }}$ ed. London: Pearson, 2001.

[12] J.T. Sokol, Identity Development throughout the lifetime: an examination of Ericksonian theory, 2009. http//epublications.marquette.edu/cgi/viewcontent.cgi? Accessed 19 November 2021.

[13] "The Voice of the Lord" [Gen 3:8], Seventh-day Adventist Bible Commentary (SDABC), rev. ed., ed. Francis D. Nichol. Washington, DC: Review \& Herald, 1953-1978.

[14] "I have no husband" [John 4:17], Seventh-day Adventist Bible Commentary (SDABC), rev. ed., ed. Francis D. Nichol. Washington, DC: Review \& Herald, 1953-1978.

[15] "Sin no more" [John 8:11], Seventh-day Adventist Bible Commentary $(S D A B C)$, rev. ed., ed. Francis D. Nichol. Washington, DC: Review \& Herald, 1953-1978.

[16] "Christian Lifestyle and Behavior", Handbook of Seventh-day Adventist Theology, rev. ed., ed. Raoul Dederen. Washington, DC: Review and Herald, 2000.

[17] John Swinton and Harriet Mowat, Practical Theology and Qualitative Research, $2^{\text {nd }}$ Ed. London: scm press, 2016.

[18] E.G. White, Education. Mountain View, CA: Pacific Press Publishing Associatin 1903

[19] E.G. White, God's Amazing Grace. Washington, DC: Review \& Herald, 1973.

[20] E.G. White, Desire of Ages. Hagerstown, MD: Review \& Herald, 2005.

[21] E.G. White, Patriarchs and Prophets. Washington, DC: Review and Herald, 2010.
[22] E.G. White, Prophets and Kings. Washington, DC: Review and Herald, 1917.

[23] E.G. White, Patriarchs and Prophets. Washington DC: Review and Herald, 2011. 